\title{
Gas Hydrate System of Shenhu Area, Northern South China Sea: Geochemical Results
}

\author{
Nengyou Wu, ${ }^{1,2,3}$ Haiqi Zhang, ${ }^{4}$ Shengxiong Yang, ${ }^{3}$ Guangxue Zhang, ${ }^{3}$ Jinqiang Liang, ${ }^{3}$ \\ Jin'an Lu, ${ }^{3}$ Xin Su, ${ }^{5}$ Peter Schultheiss, ${ }^{6}$ Melanie Holland, ${ }^{6}$ and Youhai $\mathrm{Zhu}^{7}$ \\ ${ }^{1}$ Key Laboratory of Renewable Energy and Gas Hydrate, Guangzhou Institute of Energy Conversion, CAS, Guangzhou 510640, China \\ ${ }^{2}$ Guangzhou Research Center for Gas Hydrate, CAS, Guangzhou 510640, China \\ ${ }^{3}$ Guangzhou Marine Geological Survey, Guangzhou 510075, China \\ ${ }^{4}$ China Geological Survey, Beijing 100011, China \\ ${ }^{5}$ School of Marine Sciences, China University of Geosciences, Beijing 100083, China \\ ${ }^{6}$ Geotek, Daventry NN11 8RD, UK \\ ${ }^{7}$ Institute of Mineral Resources, CAGS, Beijing 100026, China
}

Correspondence should be addressed to Nengyou Wu, wuny@ms.giec.ac.cn

Received 2 April 2011; Revised 3 August 2011; Accepted 3 August 2011

Academic Editor: Michela Giustiniani

Copyright (C) 2011 Nengyou Wu et al. This is an open access article distributed under the Creative Commons Attribution License, which permits unrestricted use, distribution, and reproduction in any medium, provided the original work is properly cited.

The drilling recovered high-concentration methane hydrates (maximum 26-48\%) in a disseminated form in silty clay sediments in Shenhu area of Pearl River Mouth Basin, South China Sea. Combining the geochemical data, the gas hydrate-bearing sediments are $10 \mathrm{~m}$ to $43 \mathrm{~m}$ in thickness and located just above the base of the gas hydrate stability zone. The methane content is $96.10-99.91 \%$ with small amount of ethane and propane. The baseline chlorinity of pore waters shows $10 \%$ lower than that of shallow sediments below and inside the gas hydrate zone. The methane/ethane ratios are higher than 1000 above the gas hydrate zone and less than 1000 at the interval of gas hydrate zone. The depth of sulphate methane interface varies from site to site as 17 to $27 \mathrm{mbsf}$. These results show that the methane of gas hydrate was mainly originated from microbial activity and the upward methane flux is minor. This is evidenced by the $\delta^{13} \mathrm{C}_{\mathrm{CH} 4}$ values of headspace gases from the gravity piston cores and released gases from pressure cores, which range from $-74.3 \%$ PDB to $-46.2 \%$ PDB, with the majority less than $-55 \%$ PDB. The hydrate deposit is a distributed gas hydrate system in Shenhu area.

\section{Introduction}

Gas hydrate is an ice-like solid substance formed by the combination of low-molecular-weight gases such as methane, ethane, and carbon dioxide with water. Gas hydrate mainly occurs naturally in sediments beneath the permafrost and the sediments of the continental slope in the water depths more than $300 \mathrm{~m}$. The marine gas hydrate is important to the economy and environment due to its enormous inventory and geohazards potential. Gas hydrate and its bearing sediments thus become an important scientific topic.

The stability of gas hydrate depends on temperature, pressure, gas composition, and pore water salinity. Nucleation and growth of gas hydrate also depends on sediment grain size, shape, and minerals [1]. These factors, which control gas hydrate formation and stability, are affected by a series of physical and chemical processes in the marine sediments and result in a variation of gas hydrate dynamics on different timescales [2-7]. Therefore, gas hydrate is not continuously distributed all over the world in the vertical and horizontal scales [8-10]. Because the geological setting and the factors controlling the gas hydrate formation are different in various locations, scientists have established different geological models based on the formation mechanisms, gas sources, and dynamics. Gas hydrate deposits can be classified into the high-flux gas hydrate deposit and low-flux gas hydrate deposit, based on the mechanisms that control gas transport into the gas hydrate stability zone, although both operate simultaneously in many regions [7].

The northern slope of South China Sea (SCS) is a passive continental margin. Geological, geophysical, and geochemical investigations for gas hydrate have been carried 


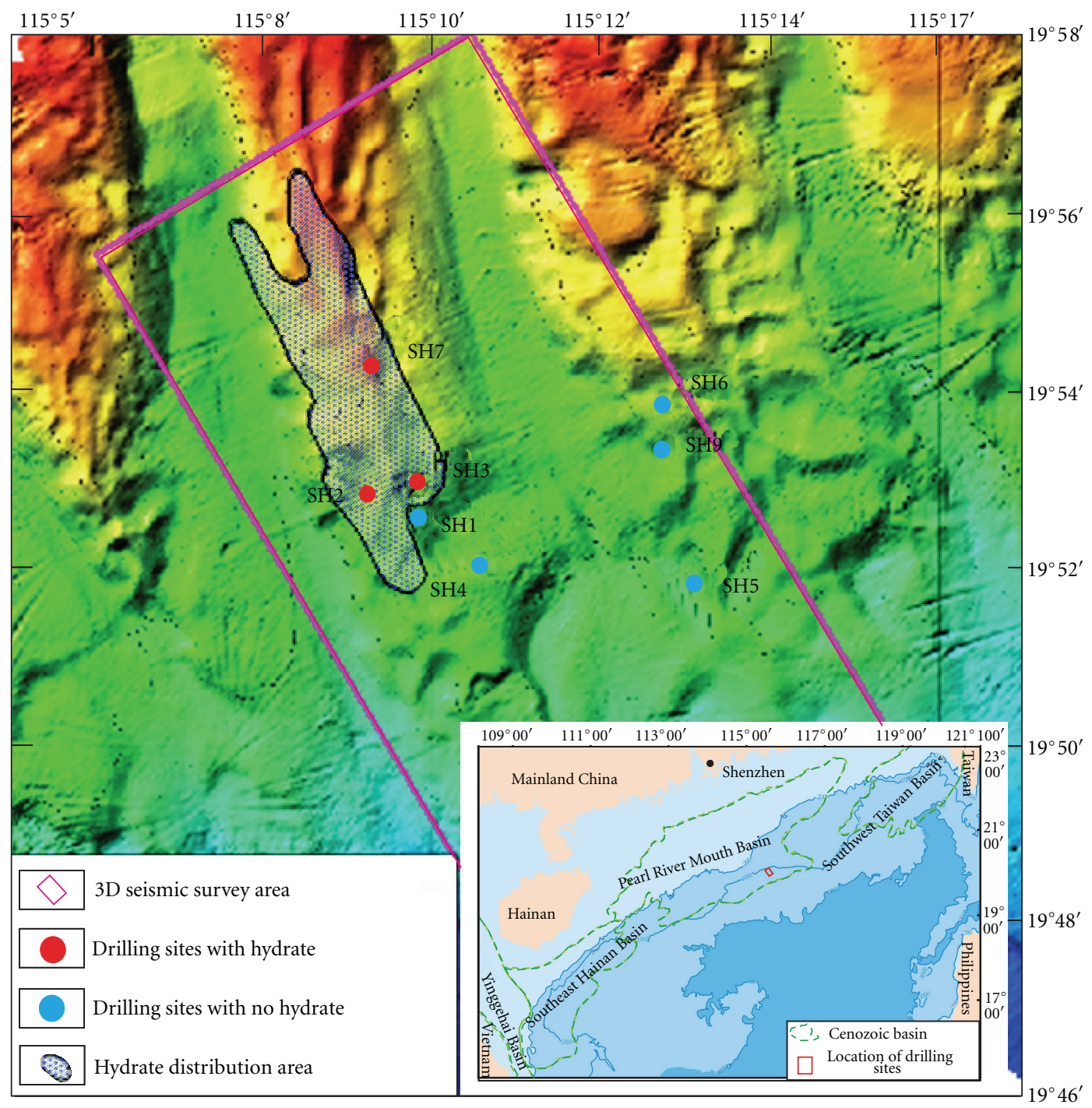

FIGURE 1: Sketch map showing the bathymetry of study area, drilling sites, and the confirmed gas hydrate distribution in Shenhu area. Insert: General location of study area in northern slope of South China Sea.

out and showed great promise for gas hydrates in this region [11-26]. Shenhu area is in the middle of the northern slope of SCS, between Xisha Trough and Dongsha Islands, and tectonically located in the Zhu II Depression, Pearl River Mouth Basin (Figure 1). The thickness of sediments is $1000-7000 \mathrm{~m}$ with $0.46-1.9 \%$ organic matter [27]. Highresolution seismic investigation shows that most of bottom simulating reflectors (BSRs) are located $150 \sim 350 \mathrm{~m}$ below seafloor [28]. The heat flow ranges from $74.0 \mathrm{~mW} \cdot \mathrm{m}^{-2}$ to $78.0 \mathrm{~mW} \cdot \mathrm{m}^{-2}$, with an average of $76.2 \mathrm{~mW} \cdot \mathrm{m}^{-2}$, and the geothermal gradient ranges from 45 to $67.7^{\circ} \mathrm{C} / \mathrm{km}$. This area has already become a large source of oil and natural gas. Therefore, originally, the gas hydrate system was thought to be the high-flux gas hydrate deposit with the thermogenic gas from a deep source in Shenhu area [28].

In order to detect the gas hydrate occurrences and determine the nature and distribution of gas hydrate, a gas hydrate drilling expedition GMGS-1 was initiated by Guangzhou Marine Geological Survey using M/V Bavenit along with specialized Fugro and Geotek in Shenhu area in 2007. Eight sites were investigated, and a pilot hole was drilled at all sites. A sampling and testing hole was drilled at sites $\mathrm{SH} 1, \mathrm{SH} 2, \mathrm{SH} 3, \mathrm{SH}$, and $\mathrm{SH} 7$. Gas hydrate bearing sediments were recovered at $\mathrm{SH} 2, \mathrm{SH} 3$ and $\mathrm{SH} 7$ which the water depth is, respectively, $1230 \mathrm{~m}, 1245 \mathrm{~m}$, and $1105 \mathrm{~m}$ (Figure 1).

From the previous geological investigations and hydrate drilling results, we present a discussion of the geochemical evidence of the gas hydrate system of Shenhu area, based on the pore-water geochemical features of core sediments and their implied gas sources, gas hydrate distribution and concentration of pore volume of sediments, and gas hydrate deposit model in this paper.

\section{Methods}

The sampling hole was used to determine the concentration, nature, and distribution of gas hydrate in the section, as well 
as the temperature gradient, the base of methane gas hydrate stability, the depth of sulphate methane interface (SMI). Both nonpressure and pressure cores were retrieved from the sampling holes with a variety of tools at depths guided by detailed wireline logs and seismic data. Nonpressure cores were sampled for pore water analysis. The results were used to quantify pore water freshening caused by gas hydrate dissociation. Plug samples of sediment were taken from centers of cores and squeezed in a hydraulic press to separate pore water for chemical analyses. Pore water salinity and chloride were measured on board, respectively by refractometry with a precision of $\pm 0.5 \mathrm{ppt}$ and by silver nitrate titration using a chromate indicator with a repeatability of $\pm 0.5 \%$. Sulfate was measured on board by ion chromatography. Baseline chlorinity profiles were constructed by the maximum measured chlorinities from the nonpressure cores and pressure cores. Pore water freshening was calculated from the difference between measured chlorinity and the estimated in situ baseline chlorinity. Gas hydrate concentration was calculated from pore water freshening, the density, and water content. The model assumes that pore space can be occupied by either pore water or gas hydrate. Gas hydrate concentration has an estimated error of $\pm 2 \%$ of pore volume.

Gas voids in nonpressure cores were sampled light hydrocarbon gases. Headspace samples were taken from near surface cores to determine the depth of SMI. A $5 \mathrm{~mL}$ plug of sediment was sealed in a $26 \mathrm{~mL}$ glass vial using a teflon-coated septum and an aluminum crimp seal. First added $2 \mathrm{~mL}$ saturated $\mathrm{NaCl}$ solution to the vial, the sediment was slurred, and the vial was placed in $60^{\circ} \mathrm{C}$ for two hours. The vials were cool down to room temperature, the headspace gas of the vial was analyzed, and the concentration of hydrocarbon in the pore waters was calculated. Gas composition was measured using an Agilent MicroGC 3000 A gas chromatograph with molecular sieve and PLOT U columns and thermal conductivity detectors. Air contamination during sampling was removed from gas totals.

Most pressure cores were depressurized in a controlled fashion to quantify the total amount of hydrocarbon gas in all phases, including gas hydrate. Gas was collected and analyzed by the on-board gas chromatograph. The released gas volume was determined by the volume of gas and fluid expelled from the system. The gas volumes were used to calculate in situ gas concentrations.

\section{Results}

3.1. The Headspace Methane and Sulfate of Pore Waters in Shallow Sediments. The headspace methane and sulfate concentration of pore waters in shallow sediments is plotted in Figures 2(a)-2(e) for sites SH1, SH2, SH3, SH5, and $\mathrm{SH} 7$ as a function of the depth. The decrease of sulfate and the increase of methane at SMI are clear. However, the change pattern of methane and sulfate curves is dissimilar and may show the varied anaerobic methane oxidation $(\mathrm{AMO})$ at different site. According to the methane and sulfate concentration profiles, the depths of SMI were determined to be $17 \mathrm{mbsf}$ to $27 \mathrm{mbsf}$ (Figure 2).
3.2. The Salinity of Pore Waters in Sediments. The salinity, sulfate and chlorinity versus depth at sites $\mathrm{SH} 2, \mathrm{SH} 3$, and SH7 are shown in Figures 3(a)-3(c). The curve is characterized by irregular and anomalous freshening spikes in the gas hydrate zone. These spikes result from the dissociation of gas hydrates during the recovery, because gas hydrates do not contain any salts.

It is clear that the curve shows a background trend towards lower salinities in the gas hydrate zone. The baseline chlorinity of pore waters in gas hydrate zone and below the base of the gas hydrate stability zone (BGHSZ) is about $10 \%$ lower than that of shallow sediments. At site $\mathrm{SH} 2$, pore water shows a slight decrease of the baseline chlorinity, for example, $570 \mathrm{mM}$ near the surface to $520 \mathrm{mM}$ at a depth of $240 \mathrm{mbsf}$. Pore water freshening is consistent between $187 \mathrm{mbsf}$ and $230 \mathrm{mbsf}$, with a gas hydrate concentration over $25 \%$ and peaking around $48 \%$ (Figure $3(\mathrm{a})$ ). At sit SH3, the baseline chlorinity decreases slightly with depth, from $565 \mathrm{mM}$ at the surface to $500 \mathrm{mM}$ at a depth of $212 \mathrm{mbsf}$. The pore water freshening is identified by pressure cores and shows the gas hydrate zone located between $190 \mathrm{mbsf}$ and $200 \mathrm{mbsf}$, with the maximum gas hydrate concentration of 26\% (Figure 3(b)). At site SH7, pore water baseline chlorinity decreases lightly as well. Pore water freshening is marked between $135 \mathrm{mbsf}$ and $178 \mathrm{mbsf}$. The maximum gas hydrate concentration is about $43 \%$ (Figure 3(c)).

Combining the geochemical data, the gas hydratebearing sediments are $10 \mathrm{~m}$ to $43 \mathrm{~m}$ in thickness and located just above BGHSZ in Shenhu area. The highest gas hydrate volume ratio appears near the base of the gas hydrate stability zone. It is very interesting that the hydrate bearing sediments compose fine grained silty clay and clay silt according to the core sediment description and grain-size analysis [29]. However, the gas hydrate concentration is very high and the maximum is about $48 \%$.

3.3. The Gas Composition and Methane/Ethane Ratio. The gas composition and methane/ethane ratio versus depth is shown in Table 1 and Figures 4(a)-4(c) for sites SH2, SH3, and SH7. The methane content is $96.10-99.91 \%$ with small amount of ethane and propane, and hence models for structure I methane hydrate. The methane/ethane ratio slightly decreases with depth above the gas hydrate zone and has a sudden change blow and inside the gas hydrate zone. The methane/ethane ratios are higher than 1000 above the gas hydrate zone and less than 1000 at the interval of gas hydrate zone and below BGHSZ.

Methane mass balance analysis of $\mathrm{SH} 2$ shows that a single depressurized core inside the hydrate zone is oversaturated with methane. This core released $26.7 \mathrm{~L}$ methane during depressurization, and gas hydrate shares $27.1 \%$. Methane is the dominant gas in headspace gas, void gas, and pressure core depressurization experiments. The methane is 96.10$99.82 \%$ and with small amount of ethane and propane. The ratio of methane to ethane is greater than 1,205 above 187 mbsf and 330-736 below 187 mbsf (Table 1, Figure 4(a)). At site $\mathrm{SH} 3$, methane is undersaturated in the sediment column near the upper resistivity anomaly, but saturated 


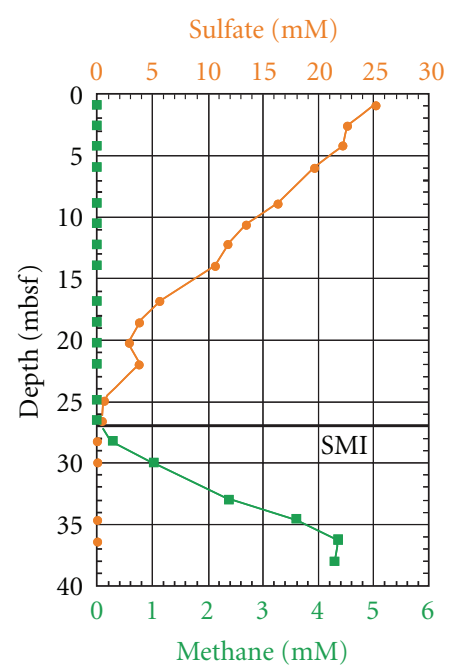

(a)

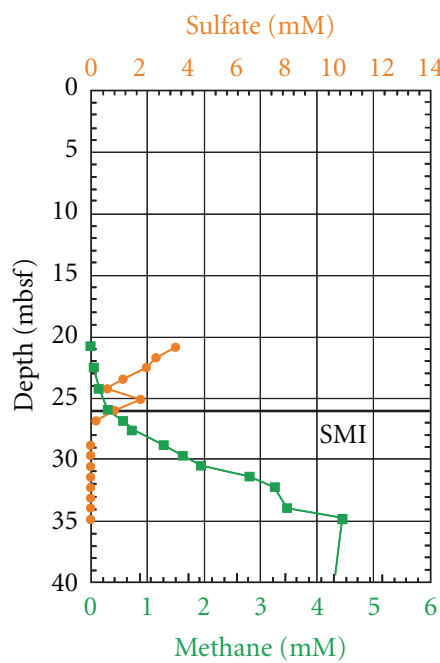

(b)

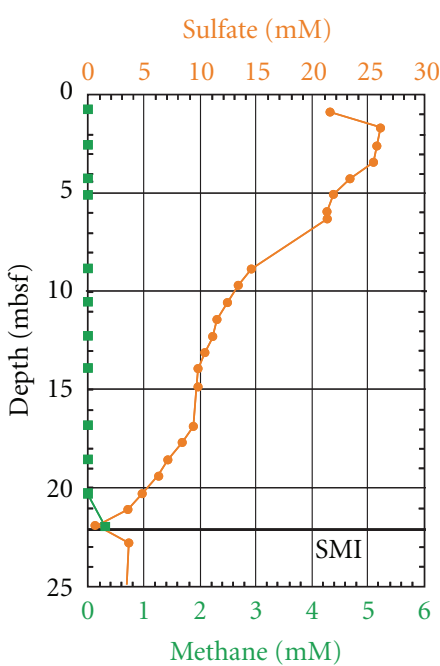

(c)

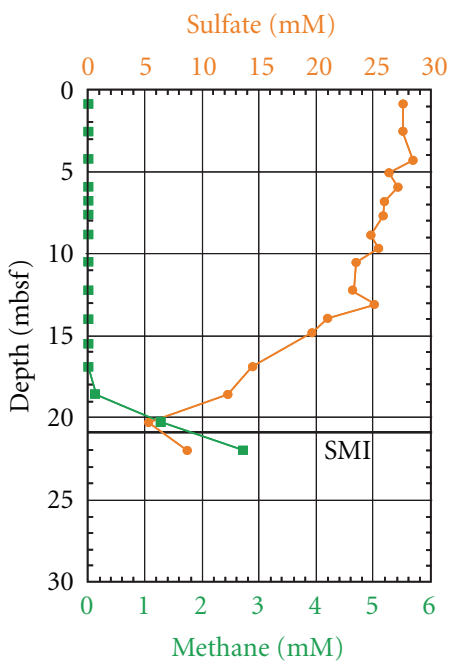

(d)

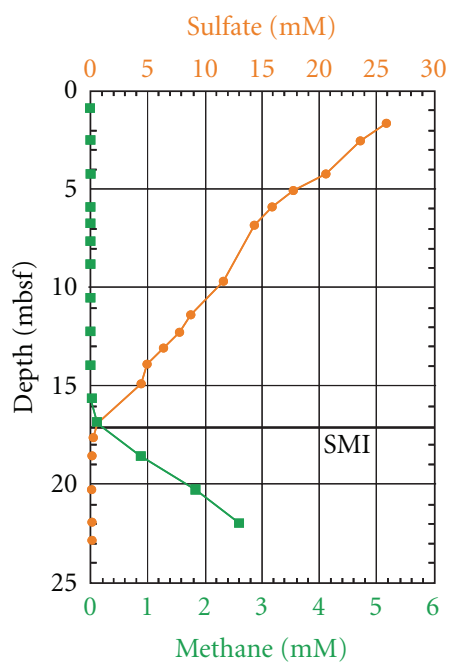

(e)

FIGURE 2: Sulfate and methane versus depth in pore waters from shallow sediments showing the decrease of sulfate and the increase of methane at the sulfate-methane interface (SMI). (a) Site SH1, (b) Site SH2, (c) Site SH3, (d) Site SH5, (e) Site SH7.

around the lower resistivity anomaly. Methane was the dominant gas in all gas samples. The average methane/ethane ratio is 1200 (Table 1, Figure 4(b)). At site SH7, one single depressurized core from inside the hydrate zone is saturated in methane. This core released over $18.7 \mathrm{~L}$ methane and occupied $27.8 \%$ gas hydrate. Methane is also the dominant gas. The average methane/ethane ratio is 4200 (Table 1, Figure 4(c)).

\section{Discussions}

4.1. Influence of Gas Hydrates on Geochemistry of Fluids. The baseline chlorinity of pore waters shows $10 \%$ lower than that of shallow sediments below and inside the gas hydrate zone, and the methane/ethane ratio presents a sudden change blow and inside the gas hydrate zone (Figure 3), showing that the gas hydrate is of the influence on the geochemistry of associated fluids. This phenomenon has been noted in the Blake Outer Ridge. Based on the analyses of gases and pore waters, Thiéry et al. investigated two aspects of the influence of gas hydrates on the geochemistry of fluids [30]. The first aspect is the presence of pore waters less saline than sea waters above and inside the gas hydrate zone because of the upward expulsion of saline waters during the compaction of sediments in the gas hydrate zone; the second one is related to the methane/ethane ratio which shows a sudden change of trend at BGHZ as gas hydrate acts as a concentration barrier for ethane [30]. Unfortunately, the incomplete coring and large spacing interval of sampling probably resulted in the nontypical phenomena in Shenhu area. However, gas hydrates dissociate and release fresh waters and methane gases that should mainly contribute to lowering the salinity of pore waters and methane/ethane ratio at the interval of gas hydrate zone.

4.2. Gas Source of Hydrate. The relative deep SMI (Figure 2) implies that upward methane flux is low, and the highest concentration of gas hydrate is near BGHSZ in Shenhu area. 

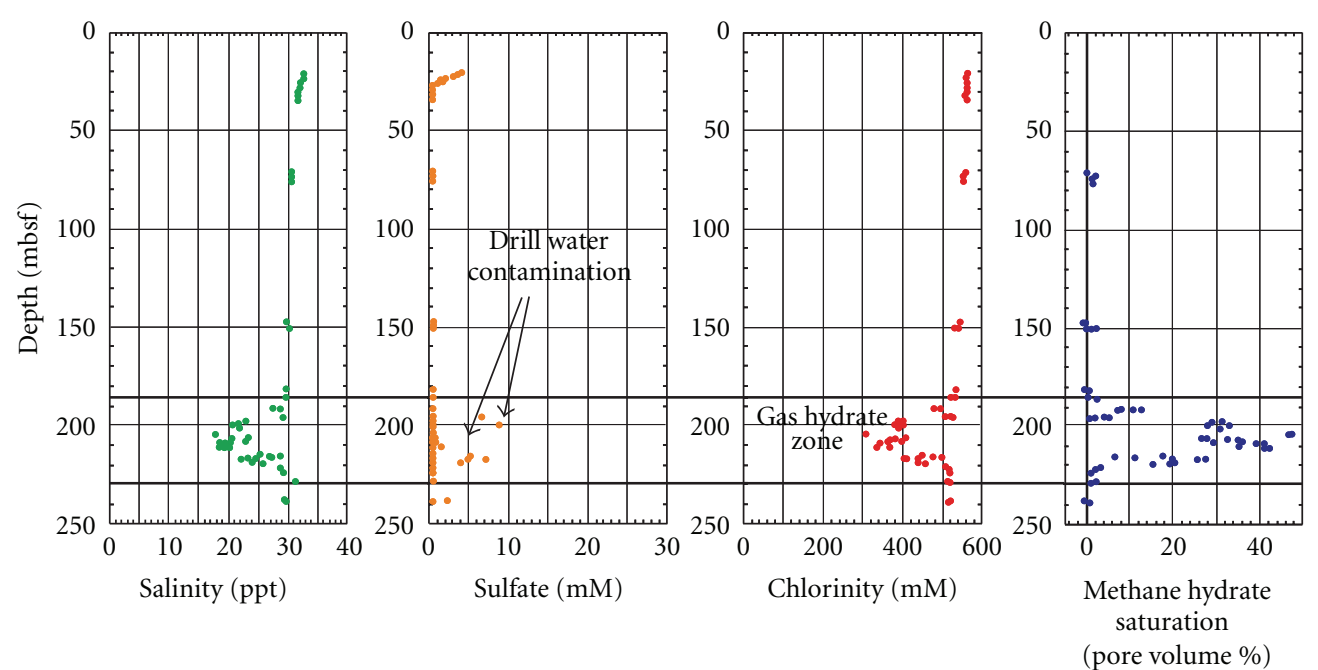

(a)
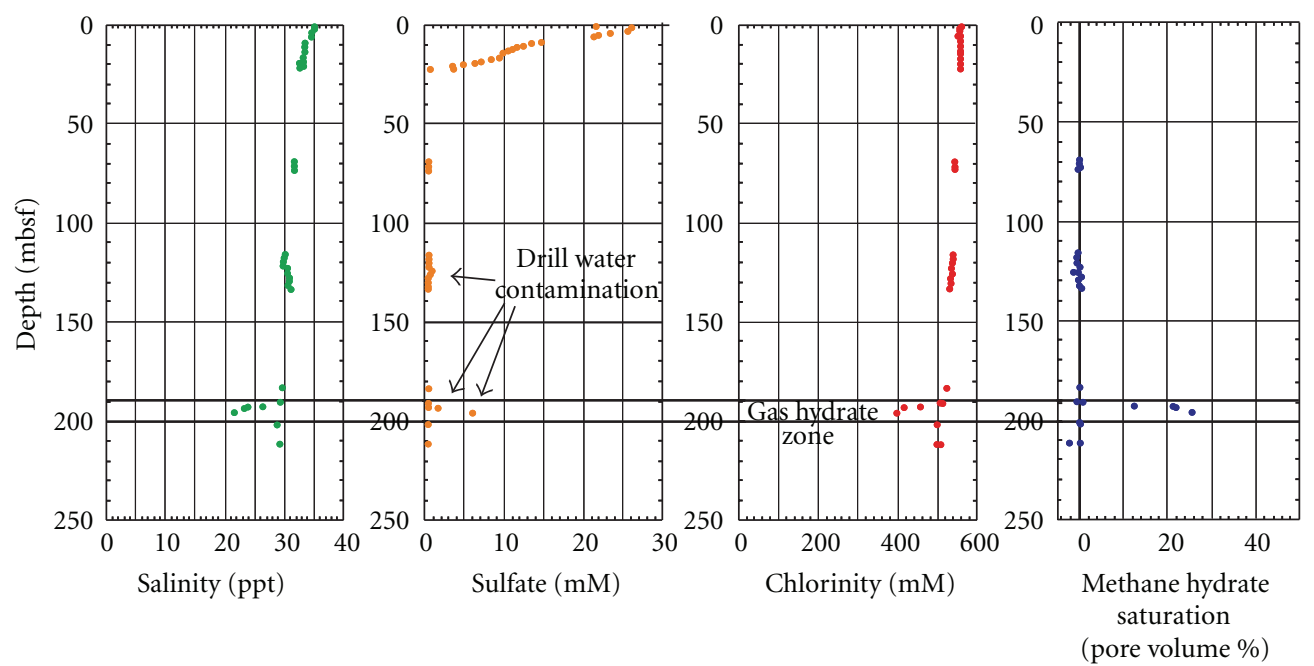

(b)
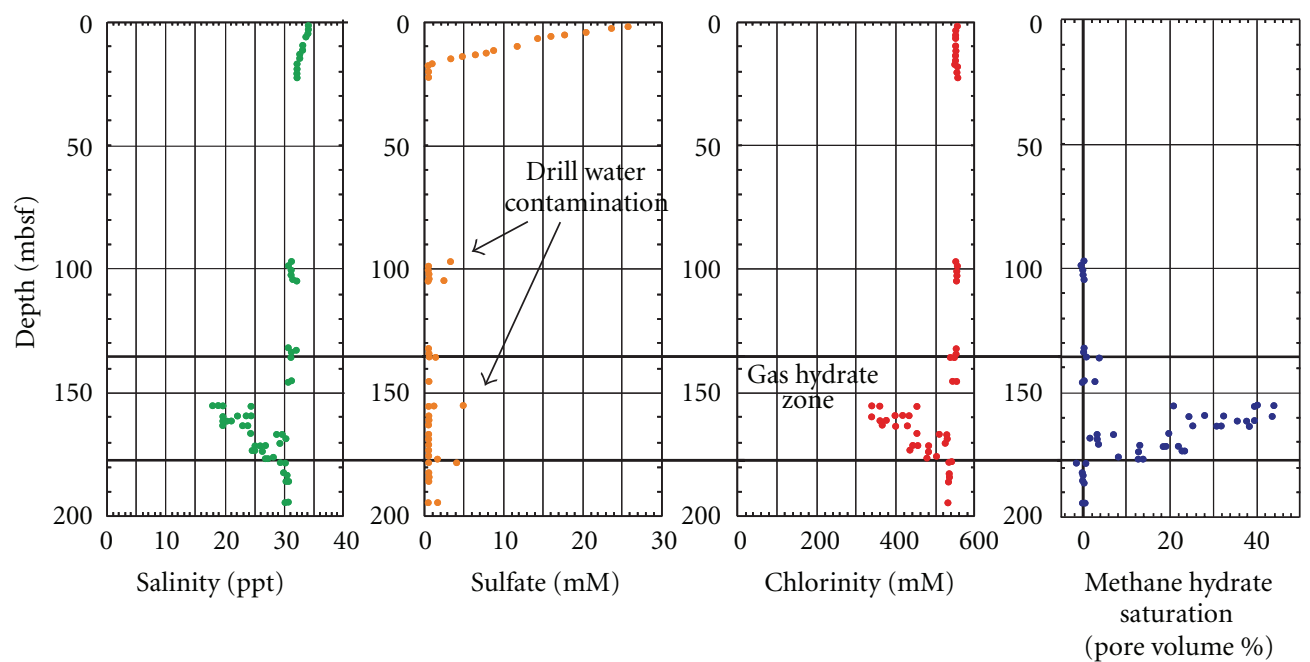

(c)

FIGURE 3: Salinity, chlorinity, and sulfate versus depth in pore waters and gas hydrate concentration versus depth at Site SH2 (a), SH3 (b) and SH7 (c). Salinity and chlorinity are corrected for drill water infiltration. Baseline chlorinity used for pore water freshening calculation. The gas hydrate-bearing sediment zone is located within 43,10 , and 40 meters above the BSR, respectively, at SH2, SH3, and SH7. 
TABLE 1: Gas composition and methane/ethane ratio in sediments of Shenhu Area, northern slope of SCS.

\begin{tabular}{|c|c|c|c|c|c|}
\hline \multirow{2}{*}{ Sample no. } & \multirow{2}{*}{ Depth (mbsf) } & \multicolumn{3}{|c|}{ Gas composition } & \multirow{2}{*}{$\mathrm{C}_{1} / \mathrm{C}_{2}$} \\
\hline & & $\mathrm{CH}_{4}(\%)$ & $\mathrm{C}_{2} \mathrm{H}_{6}(\mathrm{ppm})$ & $\mathrm{C}_{3} \mathrm{H}_{8}(\mathrm{ppm})$ & \\
\hline SH2-1 & 70.73 & 96.10 & 440 & LD & 2185 \\
\hline $\mathrm{SH} 2-2$ & 73.31 & 96.72 & 477 & LD & 2027 \\
\hline $\mathrm{SH} 2-3$ & 146.46 & 98.49 & 646 & 97 & 1524 \\
\hline $\mathrm{SH} 2-4$ & 146.89 & 98.02 & 632 & 88 & 1551 \\
\hline $\mathrm{SH} 2-5$ & 150.00 & 99.53 & 552 & 67 & 1804 \\
\hline SH2-6 & 150.00 & 96.60 & 494 & $\mathrm{LD}$ & 1956 \\
\hline $\mathrm{SH} 2-7$ & 181.65 & 99.36 & 675 & 65 & 1473 \\
\hline $\mathrm{SH} 2-8$ & 182.07 & 97.75 & 533 & $\mathrm{LD}$ & 1833 \\
\hline SH2-9 & 185.39 & 99.21 & 581 & 61 & 1708 \\
\hline SH2-10 & 185.54 & 99.32 & 824 & 53 & 1205 \\
\hline SH2-11 & 195.40 & 99.32 & 1611 & $\mathrm{LD}$ & 616 \\
\hline SH2-12 & 197.50 & 99.82 & 1737 & $\mathrm{LD}$ & 575 \\
\hline SH2-13 & 197.50 & 99.80 & 1974 & LD & 506 \\
\hline SH2-14 & 197.50 & 99.77 & 2330 & LD & 428 \\
\hline SH2-15 & 197.50 & 99.72 & 2778 & LD & 359 \\
\hline SH2-16 & 197.50 & 99.57 & 3015 & LD & 330 \\
\hline SH2-17 & 221.71 & 99.68 & 1559 & LD & 639 \\
\hline SH2-18 & 228.00 & 99.70 & 1653 & LD & 603 \\
\hline SH2-19 & 238.58 & 99.06 & 1346 & $\mathrm{LD}$ & 736 \\
\hline SH3-1 & 68.63 & 99.12 & 632 & ND & 1569 \\
\hline SH3-2 & 71.32 & 99.78 & 692 & LD & 1443 \\
\hline SH3-3 & 74.55 & 99.77 & 640 & LD & 1560 \\
\hline SH3-4 & 117.01 & 99.77 & 644 & LD & 1548 \\
\hline SH3-5 & 117.60 & 99.80 & 658 & LD & 1516 \\
\hline SH3-6 & 119.85 & 99.69 & 618 & LD & 1613 \\
\hline SH3-7 & 121.15 & 99.83 & 703 & $\mathrm{LD}$ & 1419 \\
\hline SH3-8 & 125.00 & 99.91 & 659 & $\mathrm{LD}$ & 1516 \\
\hline SH3-9 & 125.00 & 99.89 & 695 & $\mathrm{LD}$ & 1438 \\
\hline SH3-10 & 128.71 & 99.80 & 696 & $\mathrm{LD}$ & 1434 \\
\hline SH3-11 & 129.06 & 99.73 & 661 & ND & 1510 \\
\hline SH3-12 & 132.34 & 99.78 & 726 & $\mathrm{LD}$ & 1374 \\
\hline SH3-13 & 132.80 & 99.79 & 721 & $\mathrm{LD}$ & 1385 \\
\hline SH3-14 & 190.50 & 99.87 & 1241 & ND & 805 \\
\hline SH3-15 & 190.50 & 99.87 & 1237 & ND & 807 \\
\hline SH3-16 & 190.50 & 99.21 & 1051 & ND & 944 \\
\hline SH3-17 & 192.95 & 99.21 & 3587 & ND & 277 \\
\hline SH3-18 & 201.31 & 99.85 & 1376 & ND & 718 \\
\hline SH3-19 & 201.70 & 99.73 & 2209 & ND & 451 \\
\hline SH7-1 & 97.52 & 97.52 & 158 & 84 & 6161 \\
\hline SH7-2 & 99.53 & 98.19 & 188 & 67 & 5233 \\
\hline SH7-3 & 100.83 & 97.40 & 139 & 70 & 6989 \\
\hline SH7-4 & 104.00 & 99.86 & 159 & 67 & 6286 \\
\hline SH7-5 & 131.81 & 96.44 & 80 & $\mathrm{LD}$ & 11995 \\
\hline SH7-6 & 132.84 & 95.56 & 102 & $\mathrm{LD}$ & 9377 \\
\hline SH7-7 & 135.00 & 99.68 & 88 & 55 & 11315 \\
\hline SH7-8 & 135.00 & 99.47 & 124 & 61 & 8009 \\
\hline SH7-9 & 155.00 & 99.89 & 1066 & ND & 937 \\
\hline SH7-10 & 155.00 & 99.85 & 1042 & ND & 958 \\
\hline SH7-11 & 155.00 & 99.84 & 1017 & ND & 981 \\
\hline SH7-12 & 155.00 & 99.81 & 1137 & ND & 878 \\
\hline
\end{tabular}


TABLE 1: Continued.

\begin{tabular}{|c|c|c|c|c|c|}
\hline \multirow{2}{*}{ Sample no. } & \multirow{2}{*}{ Depth (mbsf) } & \multicolumn{3}{|c|}{ Gas composition } & \multirow{2}{*}{$\mathrm{C}_{1} / \mathrm{C}_{2}$} \\
\hline & & $\mathrm{CH}_{4}(\%)$ & $\mathrm{C}_{2} \mathrm{H}_{6}(\mathrm{ppm})$ & $\mathrm{C}_{3} \mathrm{H}_{8}(\mathrm{ppm})$ & \\
\hline SH7-13 & 155.00 & 99.74 & 1078 & ND & 925 \\
\hline SH7-14 & 168.67 & 99.55 & 2912 & ND & 342 \\
\hline SH7-15 & 176.12 & 99.21 & 7621 & ND & 130 \\
\hline SH7-16 & 185.00 & 99.76 & 2182 & ND & 457 \\
\hline SH7-17 & 185.00 & 99.54 & 2277 & LD & 437 \\
\hline
\end{tabular}

Note. Mbsf: meters below seafloor; \% of original gas, mole percent of each gas in the original sample: depressurization samples and void gas samples; ethane and propane (ppm), detection limit 50 parts per million; LD means lower than detection limit; ND means not detectable; $\mathrm{C}_{1} / \mathrm{C}_{2}$ is the molecule ratio of methane to ethane.

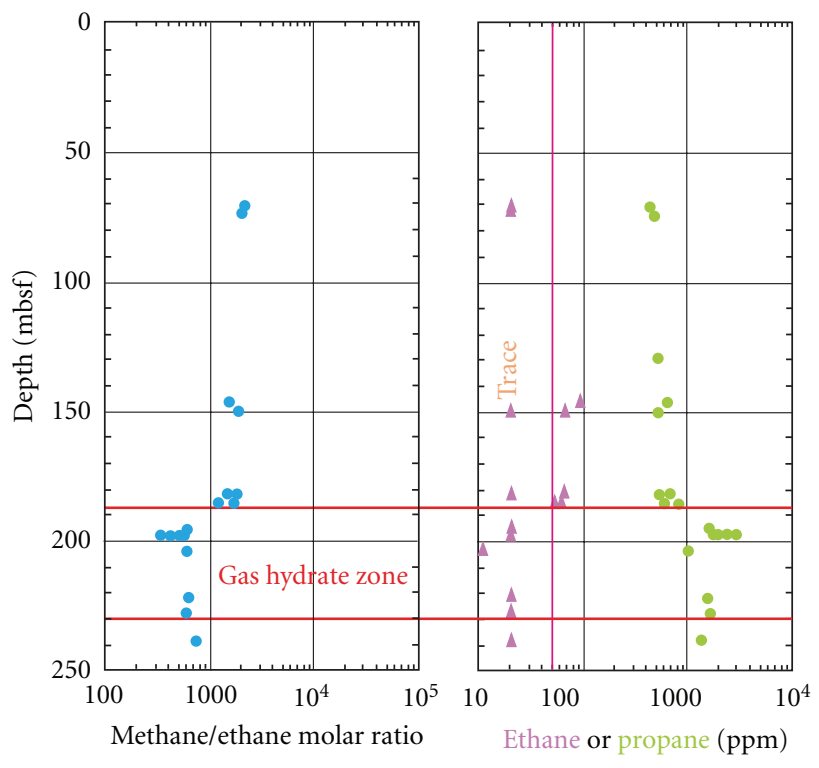

(a)

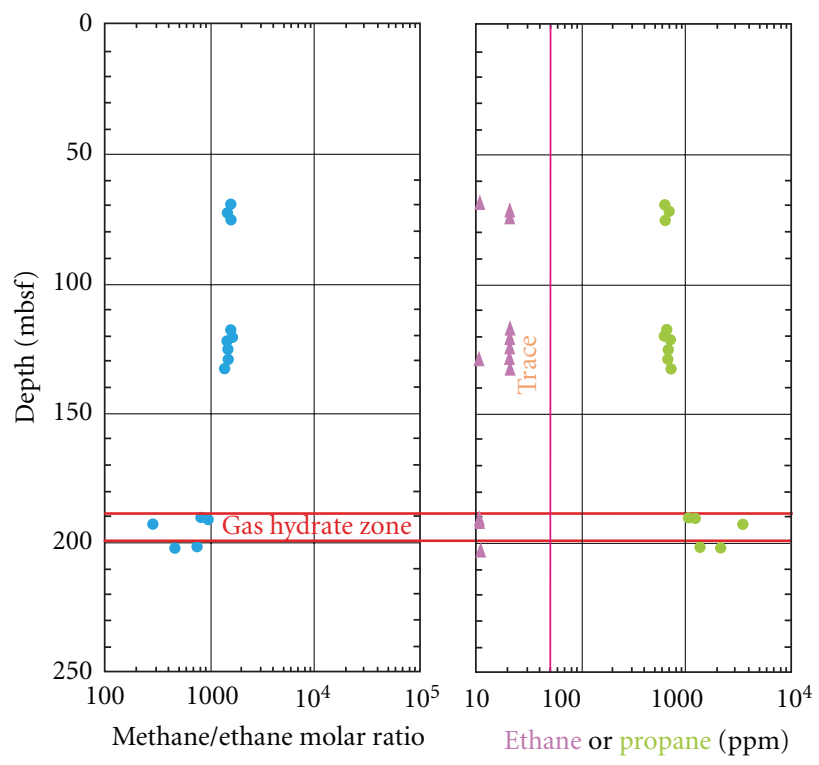

(b)

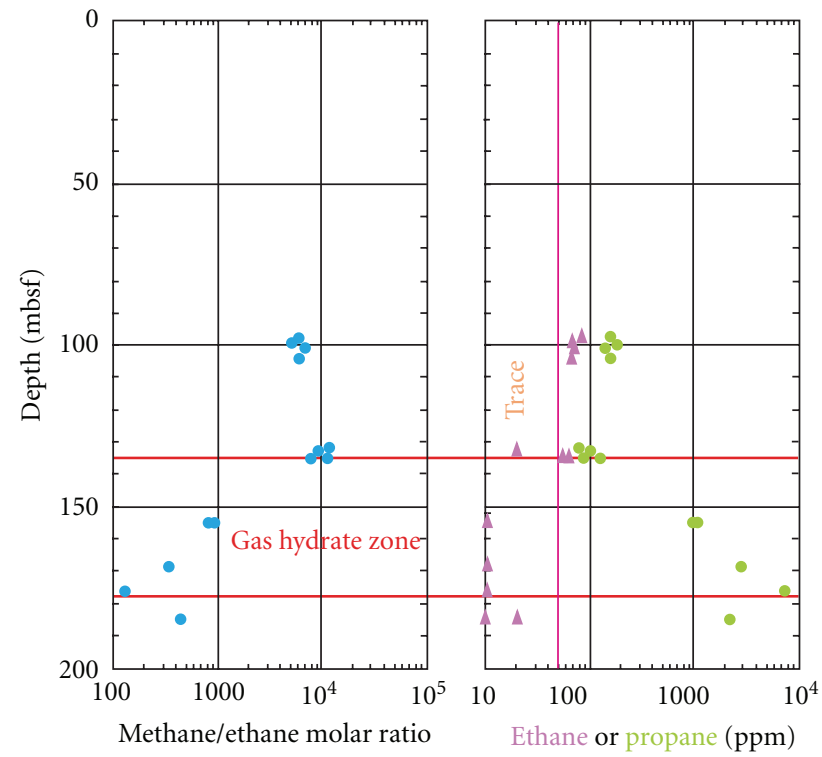

(c)

FIgURE 4: Methane/ethane versus depth at Site SH2 (a) SH3 (b), and SH7 (c). Vertical line is detection limit. 
TABLE 2: $\delta^{13} \mathrm{C}_{\mathrm{CH} 4}$ data of headspace gases from the gravity piston cores and released gases from pressure cores of Shenhu area, northern slope of SCS.

\begin{tabular}{ll}
\hline Sample no. & $\delta^{13} \mathrm{C}_{\mathrm{CH} 4}(\%, \mathrm{PDB})$ \\
\hline HS-23PC-1/7 & -57.0 \\
HS-23PC-2/7 & -62.4 \\
HS-23PC-3/7 & -64.9 \\
HS-23PC-4/7 & -62.1 \\
HS-23PC-5/7 & -61.7 \\
HS-23PC-6/7 & -59.5 \\
HS-23PC-7/7 & -69.5 \\
HS-4PC-1/7 & -60.7 \\
HS-4PC-2/7 & -62.1 \\
\hline Sample no. & $\delta^{13} \mathrm{C}_{\mathrm{CH} 4}(\% 0, \mathrm{PDB})$ \\
\hline HS-4PC-3/7 & -74.3 \\
HS-4PC-4/7 & -46.2 \\
HS-4PC-5/7 & -56.9 \\
HS-4PC-6/7 & -63.8 \\
HS-4PC-7/7 & -51.0 \\
SH2B-12R & -56.7 \\
SH3B-7P & -62.2 \\
SH5C-11R & -54.1 \\
SH3B-13P & -60.9 \\
\hline
\end{tabular}

This is similar to the gas hydrate distribution features of Blake Ridge [31] and Hydrate Ridge [8]. However, fluid advection may still be a key factor for the migration of methane-bearing fluid to the gas hydrate stability zone, if the in situ microbial methane gas production is more than our general thought. This fluid diffusion is very low, and it is not fast enough to form thick gas hydrate in reasonable geologic time scale.

There are two gas sources for the formation of gas hydrate, biogenic gas, and thermogenic gas. Biogenic methane derived anywhere organic matter and microbial populations occur [32]. AOM is the main reason for the zone of methane depletion from seafloor to SMI in marine sediments. The depth of SMI is a significant indication for methane flux in diffusion-type gas hydrate system $[33,34]$. However, hydrate can also be found on the seafloor or near the seafloor [33-37]. The formation gas hydrate on seafloor surface requires high methane fluxes and geochemical property that gas from the deeper below seafloor [7].

The current paradigm for distinguishing between microbial and thermogenic sources of methane is one that uses the relative amounts of low-molecular-weight hydrocarbon gases and $\delta^{13} \mathrm{C}_{\mathrm{CH} 4}$ values [38]. Microbial methane typically has $\delta^{13} \mathrm{C}_{\mathrm{CH} 4}$ values that range from $-90 \%$ o to $-55 \%$ (PDB) and methane/ethane ratios of $>1,000$, while thermogenic methane typically has $\delta^{13} \mathrm{C}_{\mathrm{CH} 4}$ values more positive than $-55 \%$ and methane/ethane ratios of $<100$ [38]. The $\delta^{13} \mathrm{C}_{\mathrm{CH} 4}$ values of headspace gases from the gravity piston core sediments and released gases from the pressure cores at site $\mathrm{SH} 2, \mathrm{SH} 3$, and $\mathrm{SH} 5$ range from $-74.3 \%$ PDB to $-46.2 \%$ PDB, with the majority less than
-55\% PDB (Table 2). Two gas samples from hydrate dissociation (SH2B-12R and SH3B-13P) measured, respectively, the $\delta^{13} \mathrm{C}_{\mathrm{CH} 4}$ value of $-56.7 \%$ PDB and $-60.9 \%$ PDB. The methane/ethane ratio are high, greater than 1000 above the gas hydrate zone, and less than 1000 at the interval of gas hydrate zone and below BGHSZ.

Therefore, the methane forming the gas hydrate is mainly from the microbially produced methane, not thermogenic gas from a deep source in Shenhu area, northern slope of SCS.

4.3. Gas Hydrate Distribution and Accumulation Model. GMGS-1 drilling expedition in Shenhu area shows that the thickness of hydrate-bearing sediments is $10-43 \mathrm{~m}$ with the maximum gas hydrate concentration around $48 \%$, but the depth and thickness of the gas hydrate-bearing sediments varied in different sites with similar distribution features. (i) Vertically, the gas hydrate occurs deep, and the gas hydrate-bearing sediment zone is near the bottom of BGHSZ (Figure 3), (ii) horizontally, not all BSR regions have gas hydrate, but the gas hydrate was drilled and discovered in the regions with strong BSR reflection (Figure 1), and (iii) the gas hydrate-bearing sediments are composed of fine grained silty clay or clay silt.

Gas hydrate can be classified into two categories, (i) focused, high flux gas hydrate (FHF) and (ii) distributed, low-flux gas hydrate (DLF) according to the control mechanism of gas entering the gas hydrate stability zone [7]. FHF system always forms massive gas hydrate near the seafloor, and DLF system forms the decentralized gas hydrate and in deep sediments. Shenhu area has the features of a stable tectonic setting, relatively even fine grained sediments and lower penetration rate. Clearly, the gas hydrate system may be a distributed, low-flux gas hydrate reservoir in Shenhu area, northern slope of SCS.

\section{Conclusions}

The geochemical data collected during GMGS-1 drilling expedition help us to better understand the gas hydrate system in Shenhu area of Pearl River Mouth Basin, SCS. The influence of gas hydrates on geochemistry of fluids, gas source, gas hydrate distribution and concentration of pore volume of sediments, and gas hydrate deposit model have been discussed here. The presence of less saline pore waters and sudden change of methane/ethane ratios below and inside the gas hydrate zone shows the influence of gas hydrate on the geochemistry of associated fluids. The disseminated gas hydrate in silty clay is just located above the base of the gas hydrate stability zone, with the thickness of 10-43 m and the concentration up to $48 \%$. The methane content is 96.10-99.91\% with small amount of ethane and propane. The methane/ethane ratios are higher than 1000 above the gas hydrate zone and less than 1000 at the interval of gas hydrate zone. Most of the methane gases in these fine grained sediments have been mainly produced biogenically. This is evidenced by the $\delta^{13} \mathrm{C}_{\mathrm{CH}}$ values of headspace gases from the gravity piston cores and released gases from pressure cores, 
which range from $-74.3 \%$ o PDB to $-46.2 \%$ o $\mathrm{PDB}$, with the majority less than $-55 \%$ PDB. Thus, the hydrate deposit is a distributed gas hydrate system in Shenhu area.

\section{Acknowledgments}

The gas hydrate drilling expedition aboard M/V Bavenit was planned, coordinated, and carried out by China Geological Survey. This study is financially supported by the National Natural Science Foundation of China (no. U0933004), National Basic Research Program of China (973 Program) (no. 2009CB219506), the Scientific and Technology Program of Guangdong Province (no. 2011A080403021), and Ministry of Land and Resources of China (no. 200811014). The authors wish to thank all individuals for their input and support.

\section{References}

[1] M. B. Clennell, M. Hovland, J. S. Booth, P. Henry, and W. J. Winters, "Formation of natural gas hydrates in marine sediments 1 . Conceptual model of gas hydrate growth conditioned by host sediment properties," Journal of Geophysical Research B, vol. 104, no. 10, pp. 22985-23003, 1999.

[2] G. R. Dickens, J. R. O'Neil, D. K. Rea, and R. M. Owen, "Dissociation of oceanic methane hydrate as a cause of the carbon isotope excursion at the end of the Paleocene," Paleoceanography, vol. 10, no. 6, pp. 965-971, 1995.

[3] J. P. Kennett, K. G. Cannariato, I. L. Hendy, and R. J. Behl, Methane Hydrates in Quaternary Climate Change: The Clathrate Gun Hypothesis, American Geophysical Union, Washington, DC, USA, 2003.

[4] K. Kvenvolden, "Methane hydrates and climate change," Global Biogeochemical Cycles, vol. 2, no. 3, pp. 221-229, 1988.

[5] C. K. Paull and R. Matsumoto, "Leg 164 overview," in Proceedings of the Ocean Drilling Program, Scientific Results, C. K. Paull, R. Matsumoto, and P. J. Wallace, Eds., vol. 164, pp. $3-$ 10, Ocean Drilling Program, College Station, Tex, USA, 2000.

[6] B. Buffett and D. Archer, "Global inventory of methane clathrate: sensitivity to changes in the deep ocean," Earth and Planetary Science Letters, vol. 227, no. 3-4, pp. 185-199, 2004.

[7] A. M. Tréhu, C. Ruppel, M. Holland et al., "Gas hydrates in marine sediments: lessons from scientific drilling," Oceanography, vol. 19, no. 4, pp. 124-142, 2006.

[8] A. M. Tréhu, G Bohrmann, F. R. Rack, and M. E. Torres, Proceedings of the Ocean Drilling Program, Initial Reports, vol. 204, Texas A\&M University, College Station (Ocean Drilling Program), Tex, USA, 2003.

[9] S. Bünz, J. Mienert, and C. Berndt, "Geological controls on the Storegga gas-hydrate system of the mid-Norwegian continental margin," Earth and Planetary Science Letters, vol. 209, no. 3-4, pp. 291-307, 2003.

[10] X. Su, "Marine gas hydrate distribution and gas-watersediments dynamic system-inspiration of ODP Leg 204 preliminary result," Science in China Series D, vol. 34, no. 12, pp. 1091-1099, 2004.

[11] B. H. Wu, G. X. Zhang, Y. H. Zhu, Z. Q. Lu, and B. Chen, "Progress of gas hydrate investigation in China offshore," Frontiers of Earth Science, vol. 10, pp. 177-189, 2003.

[12] H. B. Song, N. Y. Wu, S. G. Wu, and W. W. Jiang, "data processing and its BSR character of line 973 in the northeastern South China Sea," in The Evolution of China Margin Seas and
Its Resource Response, J. B. Li and S. Gao, Eds., pp. 182-185, China Ocean Press, Beijing, China, 2004.

[13] E. Suess, Y. Y. Huang, N .Y. Wu, X. Q. Han, and X. Su, IFM-GEOMAR Report, FS Sonne Cruise Report SO177, Leibniz Institute of Marine Sciences, Kiel, Germany, 2005.

[14] D. F. Chen, Y. Y. Huang, X. L. Yuan, and L. M. Cathles, "Seep carbonates and preserved methane oxidizing archaea and sulfate reducing bacteria fossils suggest recent gas venting on the seafloor in the Northeastern South China Sea," Marine and Petroleum Geology, vol. 22, no. 5, pp. 613-621, 2005.

[15] S. Wu, G. Zhang, Y. Huang, J. Liang, and H. K. Wong, "Gas hydrate occurrence on the continental slope of the northern South China Sea," Marine and Petroleum Geology, vol. 22, no. 3, pp. 403-412, 2005.

[16] S. Y. Jiang, T. Yang, L. Ge et al., "Geochemical evidences for gas hydrate occurrence in the northern margin of the South China Sea," in Proceedings of the Western Pacific Geophysics Meeting, vol. 87, Eos Transactions of American Geophysical Union, 2006, Abstract, OS44B-01.

[17] S. Y. Jiang, T. Yang, L. Ge et al., "Geochemistry of pore waters from the Xisha Trough, northern South China Sea and their implications for gas hydrates," Journal of Oceanography, vol. 64, no. 3, pp. 459-470, 2008.

[18] N. Y. Wu, H. L. Dong, E. Suess et al., "Mineralogical features and $\mathrm{C}-\mathrm{O}$ isotope composition of methane-derived carbonate build-up found in the northeastern South China Sea," in Proceedings of the Western Pacific Geophysics Meeting, vol. 87, Eos Transactions of American Geophysical Union, 2006, Abstract, OS41F-01.

[19] N. Y. Wu, S. Y. Fu, E. Suess, B. Domeyer, Y. Y. Huang, and Y. H. Zhu, "Pore-water geochemistry of surface sediments from Haiyang 4 Area of the northeastern South China Sea," in Proceedings of the Western Pacific Geophysics Meeting, vol. 87, Eos Transactions of American Geophysical Union, 2006, Abstract, OS31A-0098.

[20] T. Yang, S. Y. Jiang, J. H. Yang et al., "Dissolved inorganic carbon (DIC) and its carbon isotopic composition in sediment pore waters from the Shenhu area, northern South China Sea," Journal of Oceanography, vol. 64, no. 2, pp. 303-310, 2008.

[21] T. F. Yang, C. S. Liu, J. C. Chen, and C. Y. Huang, "Preface to the special issue on gas hydrate research around the South China Sea and Taiwan," Terrestrial, Atmospheric and Oceanic Sciences, vol. 17, no. 4, pp. I-VI, 2006.

[22] T. F. Yang, P. C. Chuang, S. Lin, J. C. Chen, Y. Wang, and S. H. Chung, "Methane venting in gas hydrate potential area offshore of SW Taiwan: evidence of gas analysis of water column samples," Terrestrial, Atmospheric and Oceanic Sciences, vol. 17, no. 4, pp. 933-950, 2006.

[23] C. S. Liu, P. Schnürle, Y. Wang, S. H. Chung, S. C. Chen, and T. H. Hsiuan, "Distribution and characters of gas hydrate offshore of southwestern Taiwan," Terrestrial, Atmospheric and Oceanic Sciences, vol. 17, no. 4, pp. 615-644, 2006.

[24] S. Lin, W. C. Hsieh, Y. C. Lim, T. F. Yang, C. S. Liu, and Y. Wang, "Methane migration and its influence on sulfate reduction in the good weather ridge region, South China Sea continental margin sediments," Terrestrial, Atmospheric and Oceanic Sciences, vol. 17, no. 4, pp. 883-902, 2006.

[25] P. C. Chuang, T. F. Yang, S. Lin et al., "Extremely high methane concentration in bottom water and cored sediments from offshore southwestern Taiwan," Terrestrial, Atmospheric and Oceanic Sciences, vol. 17, no. 4, pp. 903-920, 2006.

[26] X. Han, E. Suess, Y. Huang et al., "Jiulong methane reef: microbial mediation of seep carbonates in the South China Sea," Marine Geology, vol. 249, no. 3-4, pp. 243-256, 2008. 
[27] P. Wang, W. L. Prell, and P. Blum, "Ocean drilling program leg 184 scientific prospectus South China Sea, site 1144," in Proceedings of the Ocean Drilling Program, Initial Reports, P. Wang, W. L. Prell, and P. Blum, Eds., vol. 184, pp. 1-97, Ocean Drilling Program, College Station, Tex, USA, 2000.

[28] N. Y. Wu, H. Q. Zhang, S. X. Yang et al., "Preliminary discussion on natural gas hydrate reservoir system of Shenhu area, north slope of South China Sea," Natural Gas Industry, vol. 27, no. 9, pp. 1-6, 2007.

[29] N. Y. Wu, H. Q. Zhang, X. Su et al., "High concentrations of hydrate in disseminated forms found in very fine-grained sediments of Shenhu area, South China Sea," Terra Nostra, vol. 1-2, pp. 236-237, 2007.

[30] B. B. Bernard, J. M. Brooks, and W. M. Sackett, "Light hydrocarbons in recent Texas continental shelf and slope sediments," Journal of Geophysical Research, vol. 83, pp. 40534061, 1978.

[31] T. D. Lorenson and Leg 164 Shipboard Scientists, "Graphic summary of gas hydrate occurrence by proxy measurements across the Blake Ridge," in Proceedings of the Ocean Drilling Program, Scientific Results, C. K. Paull, R. Matsumoto, and P. J. Wallace, Eds., vol. 164, pp. 247-252, Ocean Drilling Program, College Station, Tex, USA, 2000.

[32] M. K. Davie and B. A. Buffett, "Sources of methane for marine gas hydrate: inferences from a comparison of observations and numerical models," Earth and Planetary Science Letters, vol. 206, no. 1-2, pp. 51-63, 2003.

[33] W. S. Borowski, C. K. Paull, and W. Ussler, "Marine pore-water sulfate profiles indicate in situ methane flux from underlying gas hydrate," Geology, vol. 24, no. 7, pp. 655-658, 1996.

[34] W. S. Borowski, C. K. Paull, and W. Ussler, "Global and local variations of interstitial sulfate gradients in deepwater, continental margin sediments: sensitivity to underlying methane and gas hydrates," Marine Geology, vol. 159, no. 1, pp. 131-154, 1999.

[35] J. M. Brooks, M. C. Kennicutt, R. R. Fay, T. J. McDonald, and R. Sassen, "Thermogenic gas hydrates in the Gulf of Mexico," Science, vol. 225, no. 4660, pp. 409-411, 1984.

[36] E. Suess, M. E. Torres, G. Bohrman et al., "Sea floor methane hydrate at hydrate Ridge, Cascadia Margin," in Natural Gas Hydrates: Occurrence, Distribution, and Detection, C. K. Paul and W. P. Dillon, Eds., pp. 87-98, American Geophysical Union, Washington, DC, USA, 2001.

[37] N. R. Chapman, J. W. Pohlman, R. B. Coffin, J. P. Chanton, and L. Lapham, "Thermogenic gas hydrates in the northern Cascadia Margin,” EOS Transactions, American Geophysical Union, vol. 85, no. 38, pp. 361-365, 2004.

[38] R. Thiéry, R. Bakker, C. Monnin, and The ODP Leg 164 shipboead scientific party, "Geochemistry of gas hydrates and associated fluids in the sediments of a passive continental margin: Preliminary results of the ODP Leg 164 on the Blake Outer Ridge," in Gas Hydrats Relevance to World Margin Stability and Climate Change, I. R. Henriet and J. Mienert, Eds., vol. 137, pp. 161-165, Geological Society, London, UK, 1998. 

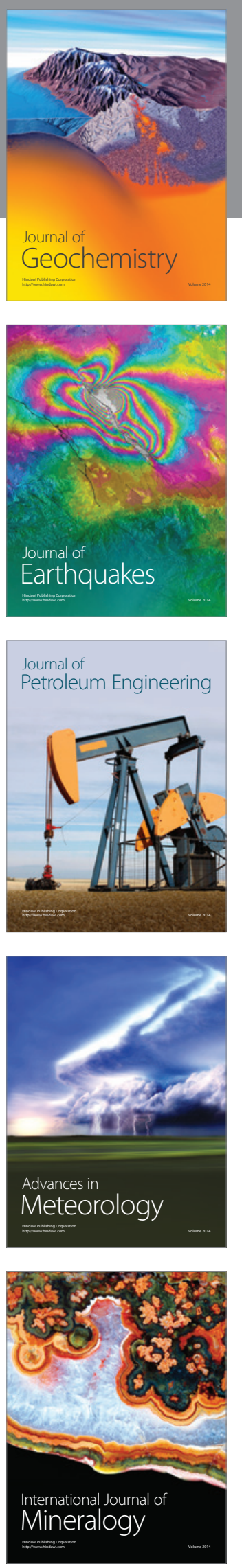
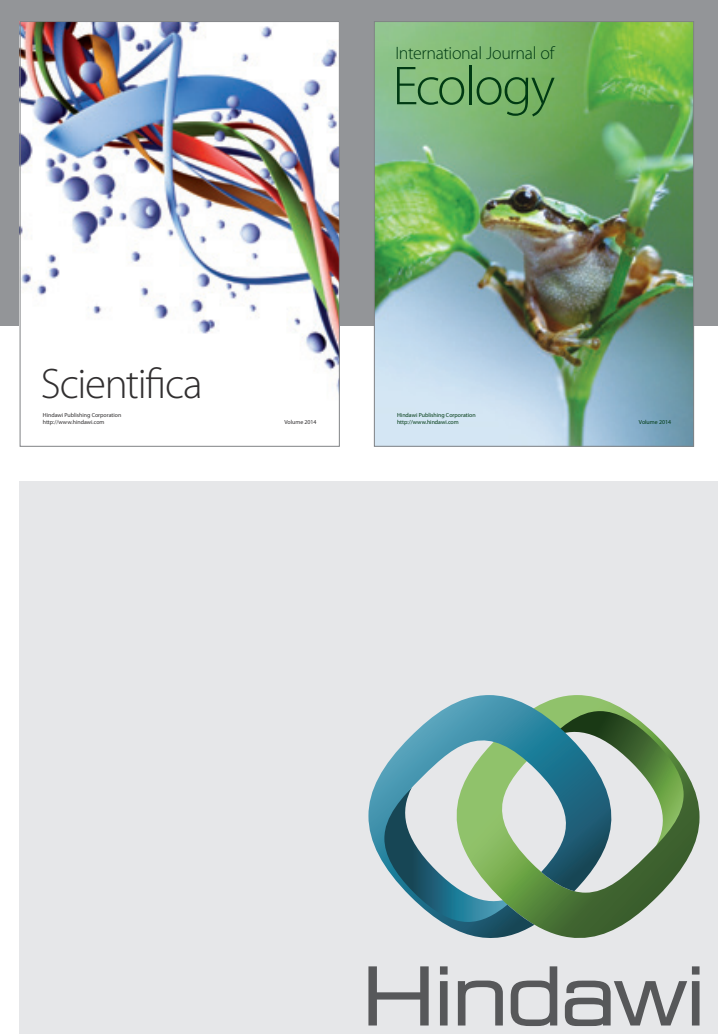

Submit your manuscripts at http://www.hindawi.com
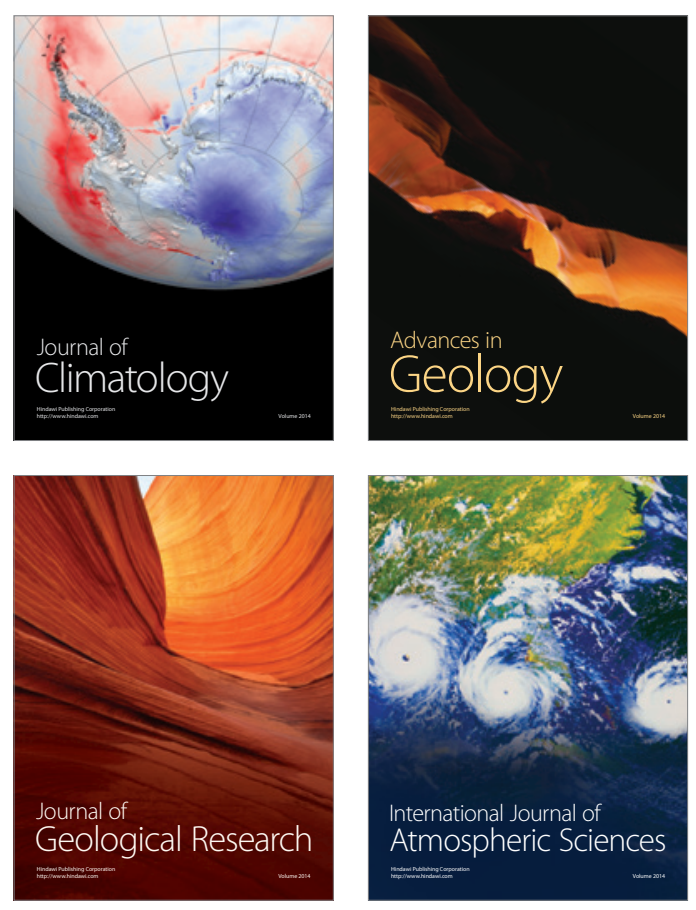
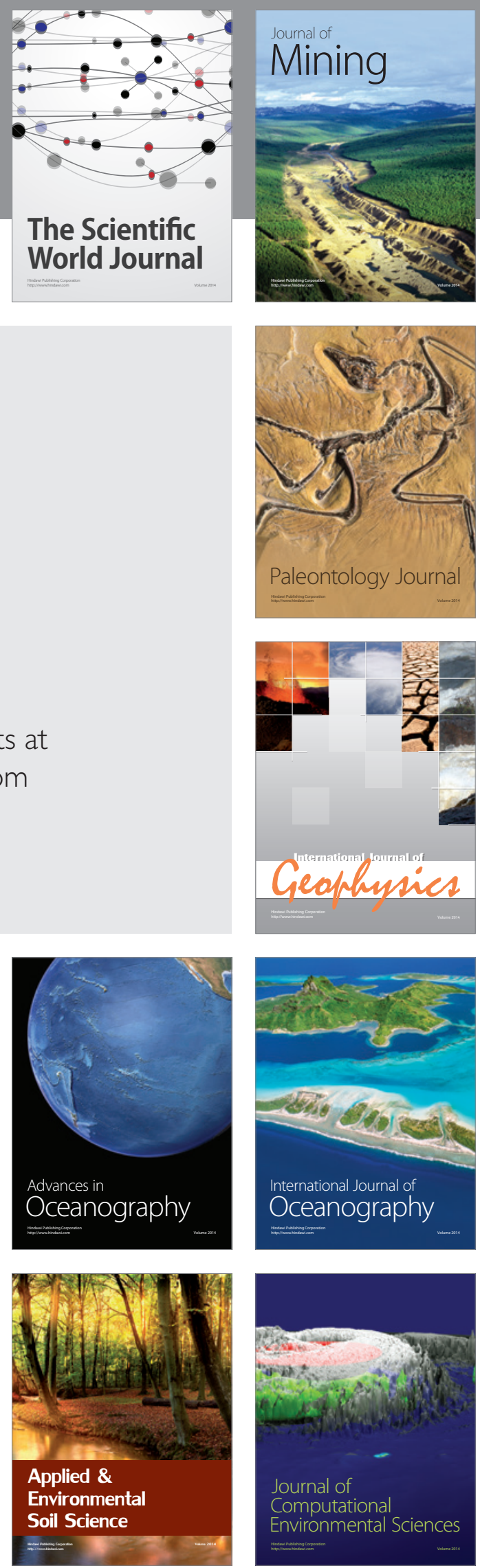